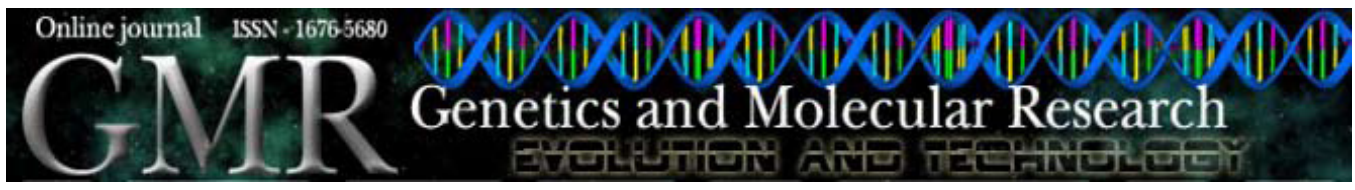

\title{
The mutagenic potential of Clusia alata (Clusiaceae) extract based on two short-term in vivo assays
}

\author{
A.C.G. Moura ${ }^{1}$, F.F. Perazzo ${ }^{1,2}$ and E.L. Maistro ${ }^{1}$ \\ 'Departamento de Fonoaudiologia, Faculdade de Filosofia e Ciências, \\ Universidade Estadual Paulista, Marília, SP, Brasil \\ ${ }^{2}$ Laboratório de Pesquisa em Fármacos, \\ Universidade Federal do Amapá, Macapá, AP, Brasil
}

Corresponding author: E.L. Maistro

E-mail: edson.maistro@marilia.unesp.br

Genet. Mol. Res. 7 (4): 1360-1368 (2008)

Received September 10, 2008

Accepted October 8, 2008

Published December 2, 2008

\begin{abstract}
We examined the genotoxic and mutagenic effects of a crude extract of Clusia alata (a potential medicinal plant) on peripheral leukocyte and bone marrow cells of mice, using the comet and chromosome aberration assays. Extracts at doses of 1000, 1500 and $2000 \mathrm{mg} /$ $\mathrm{kg}$ were administered by gavage, and a positive control, N-nitroso-Nethylurea $(50 \mathrm{mg} / \mathrm{kg})$ was injected intraperitoneally. Peripheral blood leukocytes were collected 4 and $24 \mathrm{~h}$ after the treatments for the comet assay, and bone marrow cells were collected $24 \mathrm{~h}$ after the treatments, for the chromosome aberration assay. The comet assay showed that $C$. alata extract causes an increase in damage to DNA in the peripheral blood leukocytes, but it was significant only with the $2000 \mathrm{mg} / \mathrm{kg}$ dose after $24 \mathrm{~h}$; the extract also induced a small but significant increase in the mean number of chromosome aberrations in the bone marrow cells at doses of 1500 and $2000 \mathrm{mg} / \mathrm{kg}$. No evidence of a significant decrease
\end{abstract}


in the mitotic index was observed. Acute consumption of high concentrations of $C$. alata extract produced some mutagenic effects in bone marrow cells.

Key words: Clusia alata; Comet assay; Chromosome aberrations; Single-cell gel electrophoresis

\section{INTRODUCTION}

Drugs derived from unmodified natural products or semi-synthetic drugs obtained from natural sources account for about $80 \%$ of all new drugs approved by the FDA between 1983 and 1994 (Cragg et al., 1997). This evidence supports and quantifies the importance of screening natural products.

The genus Clusia comprises about 250 species, which occur in tropical and subtropical regions of South and Central America. Its species occur in the form of shrubs, vines and small- to medium-sized trees up to $20 \mathrm{~m}$ tall, with evergreen foliage. Some species start life as epiphytes, then develop long roots that descend to the ground and eventually strangle and kill the host tree, in a manner similar to banyans. The species of this genus produce a large amount of latex, which is rich in polyprenylated benzophenones (Cerrini et al., 1993). These substances exhibit a wide range of significant biological and pharmacological activities, e.g., antiinflammatory, antimicrobial (Iinuma et al., 1996), antifungal and anti-HIV activity (Gustafson et al., 1992). Bees that pollinate these flowers collect and use the resin for nest building. Resin secretion in flowers may have originated as a defense mechanism against herbivores; and this resin can contain some toxic substances (Armbruster, 1984).

In view of the potential therapeutic use of Clusia extracts and the absence of any data on its genetic toxicity in eukaryotes, we examined the in vivo genotoxic and mutagenic effects of Clusia alata crude extract, in terms of DNA damage in peripheral blood leukocytes and the induction of chromosome aberrations in bone marrow cells of mice.

\section{MATERIAL AND METHODS}

\section{Plant material}

Dried leaves of $C$. alata $(300 \mathrm{~g})$ were submitted to dynamic maceration with ethanol $(2000 \mathrm{~mL}, 99.0 \%)$ for $4 \mathrm{~h}$. The macerate was filtered and the procedure repeated. Concentration of the extract under reduced pressure gave $27.84 \mathrm{~g}$ (yield 9.28\%) of crude ethanol extract.

\section{Chemicals}

N-nitroso-N-ethylurea (ENU, CAS No. 759-73-9) was used as the DNA damaging agent in comet and chromosome aberration assays and was dissolved in phosphate buffer, $\mathrm{pH}$ 6 . The other main chemicals were obtained from the following suppliers: normal melting point agarose (Cat. No. 15510-019; Invitrogen); low melting point agarose (Cat. No. 15517-014; Invitrogen); sodium salt $N$-lauroyl sarcosine (L-5125; Sigma) and ethylenediaminetetraacetic acid (EDTA; Merck). 


\section{Animals and assay procedures}

The experiments were carried out in 12-week-old male Swiss albino mice (Mus musculus), weighing 25-30 g. The animals were acquired from the animal house of the Universidade Estadual Paulista (UNESP), Botucatu, State of São Paulo, Brazil, and kept in polyethylene boxes $(\mathrm{N}=6)$, in a climate-controlled environment $\left(25 \pm 4^{\circ} \mathrm{C}, 55 \pm 5 \%\right.$ humidity $)$ with a 12-h light/dark cycle (7:00 am to 7:00 pm). Food (Nuvital CR1 - Nuvital) and water were available ad libitum. Animals were divided into two experimental groups of six animals each. Clusia alata extract was administered in a single dose of $0.5 \mathrm{~mL}$ by gavage, at concentrations of 1000,1500 , and $2000 \mathrm{mg} / \mathrm{kg}$ body weight, chosen on the basis of our acute toxicity studies in mice, which was above $2000 \mathrm{mg} / \mathrm{kg}$. The negative control group received distilled water. The positive control group received an intraperitoneal injection of ENU at $0.05 \mathrm{~g} / \mathrm{kg}$.

The chromosome aberration (CA) assay was performed on bone marrow cells, according to recommendations of Preston et al. (1987a). Swiss mice were injected intraperitoneally with $0.4 \mathrm{~mL} 0.16 \%$ colchicine, $120 \mathrm{~min}$ before euthanasia, which occurred $24 \mathrm{~h}$ after the experimental treatment. Bone marrow cells were collected from one femur by flushing in $\mathrm{KCl}$ $\left(0.075 \mathrm{M}\right.$, at $\left.37^{\circ} \mathrm{C}\right)$, and incubated at $37^{\circ} \mathrm{C}$ for $25 \mathrm{~min}$. The material was centrifuged and the cell pellet was fixed in aceto-methanol (acetic-acid:methanol, 1:3, v/v). Centrifugation and fixation (in the cold) were repeated three times, and the final suspension was prepared in 0.5 $\mathrm{mL}$ fixative, dropped onto slides, flame dried, and stained the following day in $5 \%$ buffered Giemsa, $\mathrm{pH}$ 6.8. Cytogenetic analysis of the slides was performed with a light microscope using a 100X oil immersion lens. One hundred well-spread metaphases containing $40 \pm 2$ chromosomes were analyzed per animal in a blind test, making up a total of 600 metaphases per control and treatment group. CAs were classified according to Savage (1976) as gaps, breaks, deletions, fragments, rings, and dicentric chromosomes. Since the cytogenetic significance of the gaps is still not well established, the statistical analysis was carried out excluding gaps. The mitotic index (MI) was calculated for 1000 cells per animal, totaling 6000 cells per group. MI values are reported as percent in this study.

The comet assay (single-cell gel electrophoresis, SCGE) was carried out by the method described by Speit and Hartmann (1999), which is based on the original study of Singh et al. (1988) and includes modifications introduced by Klaude et al. (1996), with additional modifications. Four and $24 \mathrm{~h}$ after the treatment, peripheral blood leukocytes from Swiss mice were collected. A $10-\mu \mathrm{L}$ aliquot of cells from each animal was mixed with $120 \mu \mathrm{L} 0.5 \%$ low melting point agarose at $37^{\circ} \mathrm{C}$, and rapidly spread onto microscope slides pre-coated with $1.5 \%$ normal melting point agarose. Coverslips were added and the slides were allowed to gel at $4{ }^{\circ} \mathrm{C}$ for $20 \mathrm{~min}$. The coverslips were gently removed and the slides were then immersed in cold, freshly prepared lysing solution consisting of $89 \mathrm{~mL}$ of a stock solution $(2.5 \mathrm{M} \mathrm{NaCl}$, $100 \mathrm{mM}$ EDTA, $10 \mathrm{mM}$ Tris, $\mathrm{pH}$ set to 10.0 with $\sim 8 \mathrm{~g}$ solid $\mathrm{NaOH}, 890 \mathrm{~mL}$ distilled water and $1 \%$ sodium lauryl sarcosine), plus $1 \mathrm{~mL}$ Triton X-100 (Merck) and $10 \mathrm{~mL}$ dimethylsulfoxide (Merck). The slides were left to stand at $4^{\circ} \mathrm{C}$, protected from light, for $1 \mathrm{~h}$ and then placed in the gel box, positioned at the anode end, and left in a high $\mathrm{pH}(>13)$ electrophoresis buffer $(300 \mathrm{mM} \mathrm{NaOH}$ per $1 \mathrm{mM}$ EDTA, prepared from a stock solution of $10 \mathrm{~N} \mathrm{NaOH}$ and $200 \mathrm{mM}$ EDTA, $\mathrm{pH} 10.0$ ) at $4^{\circ} \mathrm{C}$ for 20 min prior to electrophoresis, to allow the DNA to unwind. The electrophoresis run was carried out in an ice bath $\left(4^{\circ} \mathrm{C}\right)$ for $20 \mathrm{~min}$ at $300 \mathrm{~mA}$ and $25 \mathrm{~V}(0.722$ $\mathrm{V} / \mathrm{cm})$. The slides were then submerged in a neutralization buffer $(0.4 \mathrm{M}$ Tris-HCl, $\mathrm{pH} 7.5)$ 
for $15 \mathrm{~min}$, dried at room temperature and fixed in $100 \%$ ethyl alcohol for $10 \mathrm{~min}$. The slides were dried and stored overnight or longer, before staining. For the staining process, the slides were briefly rinsed in distilled water, covered with $30 \mu \mathrm{L} 1 \mathrm{X}$ ethidium bromide staining solution prepared from a 10X stock $(200 \mu \mathrm{g} / \mathrm{mL})$ and covered with a coverslip. The material was evaluated immediately at 400X magnification, using a fluorescence microscope (Olympus BX 50 ) with a 515-560-nm excitation filter and a 590-nm barrier filter. The animals used in this study were sacrificed by cervical dislocation. The Animal Bioethics Committee of the UNESP, Botucatu, Brazil, approved the present study on September 28, 2006 (protocol number 47/06), in accordance with the Federal Government legislation on animal care.

\section{Scoring procedures and data evaluation}

The extent and distribution of DNA damage indicated by the SCGE assay were evaluated by examining at least 100 randomly selected and non-overlapping cells on the slides, per animal. These cells were scored visually, according to tail size, into four classes, as follows: 1) class 0: no tail; 2) class 1: tail shorter than the diameter of the head (nucleus); 3) class 2: tail length 1 to 2 times the diameter of the head, and 4) class 3: tail longer than 2 times the diameter of the head. Comets with no heads and images with nearly all DNA in the tail, or with a very wide tail, were excluded from the evaluation because they probably represent dead cells (Hartmann and Speit, 1997). The total score for 100 comets was obtained by multiplying the number of cells in each class by the damage class, ranging from 0 (all undamaged) to 300 (all maximally damaged).

\section{Statistical analysis}

After verifying whether the data were normally distributed, the data obtained on chromosome aberration and SCGE assays were submitted to one-way analysis of variance (ANOVA) and the Tukey multiple comparison test (Sokal and Rohlf, 1995), using the GraphPad Instat ${ }^{\mathbb{R}}$ software (version 3.01). The results were considered to be statistically significant at $\mathrm{P}<0.05$.

\section{RESULTS AND DISCUSSION}

When conducting a thorough hazard characterization for a chemical, it is important to determine if that chemical can induce any of the various types of possible mutations. The different mutation hazard identification assays have different abilities to detect these changes (Moore and Harrington-Brock, 2000).

The ability of $C$. alata extract to induce genotoxicity and mutagenicity was assessed in our study using comet and CA assays, respectively. The in vivo comet assay (SCGE) is increasingly being used in genotoxicity testing. It can be used to detect DNA damage such as strand breaks, alkali-labile sites, DNA-DNA, and DNA-protein crosslinks (Brendler-Schwaab et al., 2005). Its advantages include applicability to various tissues and/or special cell types, its sensitivity for detecting low levels of DNA damage, and the requirement of small numbers of cells per sample, among others (Singh et al., 1988; Tice et al., 2000). This approach can detect primary DNA damage that does not necessarily reflect the adverse impact a chemical might cause to the cell, since this damage can also be repaired. The results of the $C$. alata extract by the comet assay, namely data on the total number of cells with damage and scores of mice treated with 1000,1500 , and $2000 \mathrm{mg} / \mathrm{kg}$, 
as well as the negative and positive controls (ENU, $50 \mathrm{mg} / \mathrm{kg}$ ) are presented in Tables 1 and 2 . As expected, ENU, the positive control, induced a significant increase in DNA migration in leukocytes $(\mathrm{P}<0.001)$. No statistically significant difference between treated versus untreated animals was observed for $C$. alata extract at the most of the doses tested, or at both times of leukocyte collection $(4$ and $24 \mathrm{~h})(\mathrm{P}>0.05)$. A statistically significant increase of total cells with DNA damage was observed only at the dose of $2000 \mathrm{mg} / \mathrm{kg}$ (collected after $24 \mathrm{~h} ; \mathrm{P}<0.05$ ). When exposed to three concentrations of the extract, most of the cells examined on the slides were undamaged, a few cells showed minor damage (class 1) and very few showed a large amount of damage (classes 2 and 3). Furthermore, there were no significant differences in DNA migration between the three extract concentrations tested and between the two times of leukocyte collection $(4 \mathrm{~h}$, before the DNA cell repair process, and $24 \mathrm{~h}$, after the DNA repair process).

\begin{tabular}{|c|c|c|c|c|c|c|c|}
\hline \multirow[t]{2}{*}{ Treatments } & \multirow[t]{2}{*}{ Animals } & \multirow[t]{2}{*}{ Total $^{1}$} & \multicolumn{4}{|c|}{ Comet class } & \multirow[t]{2}{*}{ Scores } \\
\hline & & & 0 & 1 & 2 & 3 & \\
\hline \multirow[t]{7}{*}{ Control } & $\mathrm{M}_{1}$ & 15 & 85 & 14 & 1 & 0 & 16 \\
\hline & $\mathrm{M}_{2}$ & 13 & 87 & 12 & 1 & 0 & 14 \\
\hline & $\mathrm{M}_{3}$ & 9 & 91 & 8 & 1 & 0 & 10 \\
\hline & $\mathrm{M}_{4}$ & 11 & 89 & 11 & 0 & 0 & 11 \\
\hline & $\mathrm{M}_{5}$ & 11 & 89 & 9 & 2 & 0 & 13 \\
\hline & $\mathrm{M}_{6}$ & 10 & 90 & 7 & 3 & 0 & 13 \\
\hline & Mean \pm SD & $11.5 \pm 2.1$ & & & & & $12.83 \pm 2.13$ \\
\hline \multirow{7}{*}{$\begin{array}{l}\text { Clusia alata extract } \\
(1000 \mathrm{mg} / \mathrm{kg})\end{array}$} & $\mathrm{M}_{7}$ & 9 & 91 & 9 & 0 & 0 & 9 \\
\hline & $\mathrm{M}_{8}$ & 7 & 93 & 7 & 0 & 0 & 7 \\
\hline & $\mathrm{M}_{9}$ & 11 & 89 & 11 & 0 & 0 & 11 \\
\hline & $\mathrm{M}_{10}$ & 10 & 90 & 10 & 0 & 0 & 10 \\
\hline & $\mathrm{M}_{11}$ & 7 & 93 & 7 & 0 & 0 & 7 \\
\hline & $\mathrm{M}_{12}$ & 9 & 91 & 9 & 0 & 0 & 9 \\
\hline & Mean \pm SD & $8.8 \pm 1.6$ & & & & & $8.83 \pm 1.60$ \\
\hline \multirow{7}{*}{$\begin{array}{l}\text { Clusia alata extract } \\
(1500 \mathrm{mg} / \mathrm{kg})\end{array}$} & $\mathrm{M}_{13}$ & 15 & 85 & 14 & 1 & 0 & 16 \\
\hline & $\mathrm{M}_{14}$ & 10 & 90 & 10 & 0 & 0 & 10 \\
\hline & $\mathrm{M}_{15}$ & 11 & 89 & 9 & 2 & 0 & 13 \\
\hline & $\mathrm{M}_{16}$ & 10 & 90 & 10 & 0 & 0 & 10 \\
\hline & $\mathrm{M}_{17}$ & 12 & 88 & 11 & 1 & 0 & 13 \\
\hline & $\mathrm{M}_{18}$ & 12 & 88 & 10 & 2 & 0 & 14 \\
\hline & Mean \pm SD & $11.6 \pm 1.8$ & & & & & $12.66 \pm 2.33$ \\
\hline \multirow{7}{*}{$\begin{array}{l}\text { Clusia alata extract } \\
(2000 \mathrm{mg} / \mathrm{kg})\end{array}$} & $\mathrm{M}_{19}$ & 12 & 88 & 12 & 0 & 0 & 12 \\
\hline & $\mathrm{M}_{20}$ & 14 & 86 & 14 & 0 & 0 & 14 \\
\hline & $M_{21}$ & 12 & 88 & 11 & 1 & 0 & 13 \\
\hline & $\mathrm{M}_{22}$ & 16 & 84 & 16 & 0 & 0 & 16 \\
\hline & $\mathrm{M}_{23}$ & 12 & 88 & 11 & 1 & 0 & 13 \\
\hline & $\mathrm{M}_{24}$ & 9 & 91 & 9 & 0 & 0 & 9 \\
\hline & Mean \pm SD SD & $12.5 \pm 2.3$ & & & & & $12.83 \pm 2.31$ \\
\hline \multirow{7}{*}{$\begin{array}{l}\text { N-nitroso-N-ethylurea } \\
(50 \mathrm{mg} / \mathrm{kg})\end{array}$} & $\mathrm{M}_{25}$ & 66 & 34 & 64 & 2 & 0 & 68 \\
\hline & $\mathrm{M}_{26}$ & 58 & 42 & 57 & 1 & 0 & 59 \\
\hline & $\mathrm{M}_{27}$ & 64 & 36 & 62 & 2 & 0 & 66 \\
\hline & $\mathrm{M}_{28}$ & 70 & 30 & 68 & 2 & 0 & 72 \\
\hline & $\mathrm{M}_{29}$ & 70 & 30 & 66 & 4 & 0 & 74 \\
\hline & $\mathrm{M}_{30}$ & 56 & 44 & 54 & 2 & 0 & 58 \\
\hline & Mean \pm SD & $64.0 \pm 5.9^{*}$ & & & & & $66.1 \pm 6.58^{*}$ \\
\hline
\end{tabular}

\footnotetext{
*Significantly different from the negative control $(\mathrm{P}<0.001) .{ }^{1}$ Total number of damaged cells (classes $\left.1+2+3\right)$.
} 
Table 2. DNA migration in the comet assay for the assessment of genotoxicity of Clusia alata extract in peripheral blood cells (collected $24 \mathrm{~h}$ after the treatment) from male (M) Swiss mice in vivo.

\begin{tabular}{|c|c|c|c|c|c|c|c|}
\hline \multirow[t]{2}{*}{ Treatments } & \multirow[t]{2}{*}{ Animals } & \multirow[t]{2}{*}{ Total $^{1}$} & \multicolumn{4}{|c|}{ Comet class } & \multirow[t]{2}{*}{ Scores } \\
\hline & & & 0 & 1 & 2 & 3 & \\
\hline \multirow[t]{7}{*}{ Control } & $\mathrm{M}_{1}$ & 5 & 95 & 5 & 0 & 0 & 5 \\
\hline & $\mathrm{M}_{2}$ & 4 & 96 & 4 & 0 & 0 & 4 \\
\hline & $\mathrm{M}_{3}$ & 5 & 95 & 5 & 0 & 0 & 5 \\
\hline & $\mathrm{M}_{4}$ & 6 & 94 & 6 & 0 & 0 & 6 \\
\hline & $\mathrm{M}_{5}$ & 10 & 90 & 10 & 0 & 0 & 10 \\
\hline & $\mathrm{M}_{6}$ & 6 & 94 & 5 & 1 & 0 & 7 \\
\hline & Mean \pm SD & $6.0 \pm 2.0$ & & & & & $6.16 \pm 2.13$ \\
\hline \multirow{7}{*}{$\begin{array}{l}\text { Clusia alata extract } \\
(1000 \mathrm{mg} / \mathrm{kg})\end{array}$} & $\mathrm{M}_{7}$ & 14 & 86 & 14 & 2 & 0 & 14 \\
\hline & $\mathrm{M}_{8}$ & 9 & 91 & 9 & 0 & 0 & 9 \\
\hline & $\mathrm{M}_{9}$ & 10 & 90 & 10 & 1 & 0 & 10 \\
\hline & $\mathrm{M}_{10}$ & 10 & 90 & 9 & 1 & 0 & 11 \\
\hline & $\mathrm{M}_{11}$ & 8 & 92 & 8 & 0 & 0 & 8 \\
\hline & $\mathrm{M}_{12}$ & 11 & 89 & 11 & 1 & 0 & 11 \\
\hline & Mean \pm SD & $10.3 \pm 2.0$ & & & & & $10.5 \pm 2.07$ \\
\hline \multirow{7}{*}{$\begin{array}{l}\text { Clusia alata extract } \\
(1500 \mathrm{mg} / \mathrm{kg})\end{array}$} & $\mathrm{M}_{13}$ & 6 & 94 & 5 & 1 & 0 & 7 \\
\hline & $\mathrm{M}_{14}$ & 13 & 87 & 12 & 1 & 0 & 14 \\
\hline & $\mathrm{M}_{15}$ & 8 & 92 & 6 & 1 & 1 & 8 \\
\hline & $\mathrm{M}_{16}$ & 11 & 89 & 10 & 1 & 0 & 12 \\
\hline & $\mathrm{M}_{17}$ & 9 & 91 & 9 & 0 & 0 & 9 \\
\hline & $\mathrm{M}_{18}$ & 12 & 88 & 9 & 2 & 1 & 16 \\
\hline & Mean \pm SD & $9.8 \pm 2.6$ & & & & & $11.0 \pm 3.57$ \\
\hline \multirow{7}{*}{$\begin{array}{l}\text { Clusia alata extract } \\
(2000 \mathrm{mg} / \mathrm{kg})\end{array}$} & $\mathrm{M}_{19}$ & 10 & 90 & 10 & 0 & 0 & 10 \\
\hline & $\mathrm{M}_{20}$ & 7 & 93 & 7 & 0 & 0 & 7 \\
\hline & $\mathrm{M}_{21}$ & 15 & 85 & 14 & 1 & 0 & 16 \\
\hline & $\mathrm{M}_{22}^{21}$ & 13 & 87 & 11 & 2 & 0 & 15 \\
\hline & $\mathrm{M}_{23}$ & 13 & 87 & 13 & 0 & 0 & 13 \\
\hline & $\mathrm{M}_{24}$ & 15 & 85 & 15 & 0 & 0 & 15 \\
\hline & Mean \pm SD & $12.1 \pm 3.1^{*}$ & & & & & $12.66 \pm 3.50$ \\
\hline \multirow{7}{*}{$\begin{array}{l}\text { N-nitroso-N-ethylurea } \\
(50 \mathrm{mg} / \mathrm{kg})\end{array}$} & $\mathrm{M}_{25}$ & 56 & 44 & 53 & 3 & 0 & 59 \\
\hline & $\mathrm{M}_{26}$ & 52 & 48 & 51 & 1 & 0 & 53 \\
\hline & $\mathrm{M}_{27}$ & 63 & 37 & 62 & 1 & 0 & 64 \\
\hline & $\mathrm{M}_{28}$ & 64 & 36 & 62 & 2 & 0 & 66 \\
\hline & $\mathrm{M}_{29}$ & 62 & 38 & 57 & 4 & 1 & 68 \\
\hline & $\mathrm{M}_{30}$ & 67 & 33 & 64 & 3 & 0 & 70 \\
\hline & Mean \pm SD & $60.6 \pm 5.5^{* *}$ & & & & & $63.33 \pm 6.31^{* *}$ \\
\hline
\end{tabular}

*Significantly different from the negative control $(\mathrm{P}<0.05)$. **Significantly different from the negative control ( $\mathrm{P}$ $<0.001$ ). ${ }^{1}$ Total number of damaged cells (classes $1+2+3$ ).

To obtain a parameter for comparison with the SCGE assay, we also applied a CA test. The mouse in vivo CA assay has been recognized as one of the sensitive endpoints to test the mutagenicity of chemicals and/or industrial pollutants (Preston et al., 1987a). Mutagenic effects occur when the test substance induces heritable mutations (damage that can pass to daughter somatic cells). Table 3 shows data on the induction of CAs in bone marrow cells of mice following in vivo exposure to different doses of $C$. alata extract. A single exposure in mice, of three high doses of the extract, enhanced the average number of CAs at metaphase at the three doses tested, being statistically significant at doses of 1500 and $2000 \mathrm{mg} / \mathrm{kg}$. As expected, the animals treated with ENU had a significantly higher number of CAs. The CAs observed were chromatid and chromosome 
breaks, gaps, deletions, acentric fragments, and ring chromosomes. Chromatid breaks were present at higher frequencies than in the other types, and were induced by all doses tested. Although the number of gaps at the three concentrations tested of the extract was increased when compared with the control group, the gaps were excluded from the statistical analysis since they are considered by some investigators to be of debatable genetic significance, since their presence does not always lead to CAs in the subsequent cell divisions (Preston et al., 1987a; Brusik, 1987).

Table 3. Mitotic index (MI) and distribution of the different types of chromosomal aberrations (CA) observed in male (M) Swiss mice leukocytes treated with a Clusia alata extract, and respective controls.

\begin{tabular}{|c|c|c|c|c|c|c|c|c|c|}
\hline \multirow[t]{3}{*}{ Treatments } & \multirow[t]{3}{*}{ Animal } & \multirow[t]{3}{*}{ MI (\%) } & \multicolumn{4}{|c|}{ Chromosomal aberrations } & \multirow[t]{3}{*}{$\mathrm{OA}$} & \multirow{3}{*}{$\begin{array}{c}\text { Total CA } \\
\text { without gaps }\end{array}$} & \multirow{3}{*}{$\begin{array}{l}\text { Cells with } \\
\text { aberrations }\end{array}$} \\
\hline & & & \multicolumn{2}{|c|}{ Gaps } & \multicolumn{2}{|c|}{ Breaks } & & & \\
\hline & & & $\mathrm{C}$ & $\mathrm{IC}$ & $\mathrm{C}$ & $\mathrm{IC}$ & & & \\
\hline \multirow[t]{7}{*}{ Control } & $\mathrm{M}_{1}$ & 2.6 & 0 & 0 & 0 & 0 & $1 \mathrm{f}, 1 \mathrm{r}$ & 2 & 2 \\
\hline & $\mathrm{M}_{2}$ & 3.0 & 0 & 1 & 1 & 0 & 0 & 1 & 1 \\
\hline & $\mathrm{M}_{3}^{2}$ & 2.9 & 0 & 1 & 0 & 0 & $1 \mathrm{del}$ & 1 & 1 \\
\hline & $\mathrm{M}_{4}$ & 2.6 & 0 & 0 & 0 & 0 & 1f & 1 & 1 \\
\hline & $\mathrm{M}_{5}^{4}$ & 3.6 & 0 & 0 & 1 & 0 & 0 & 1 & 1 \\
\hline & $\mathrm{M}_{6}$ & 3.1 & 0 & 0 & 1 & 0 & $1 \mathrm{r}$ & 2 & 2 \\
\hline & Mean \pm SD & $2.9 \pm 0.3$ & & & & & & $1.33 \pm 0.5$ & \\
\hline \multirow{7}{*}{$\begin{array}{l}\text { Clusia alata extract } \\
(1000 \mathrm{mg} / \mathrm{kg})\end{array}$} & $\mathrm{M}_{7}$ & 3.2 & 0 & 0 & 3 & 1 & $1 \mathrm{f}$ & 5 & 5 \\
\hline & $\mathrm{M}_{8}$ & 3.7 & 0 & 2 & 3 & 0 & 0 & 3 & 3 \\
\hline & $\mathrm{M}_{9}^{8}$ & 3.2 & 0 & 2 & 1 & 0 & $1 \mathrm{f}$ & 2 & 2 \\
\hline & $\mathrm{M}_{10}$ & 4.1 & 1 & 0 & 2 & 0 & 1f & 3 & 3 \\
\hline & $M_{11}$ & 3.2 & 1 & 0 & 2 & 0 & 1r, 1del & 4 & 4 \\
\hline & $\mathrm{M}_{12}$ & 3.6 & 1 & 0 & 2 & 0 & 1f & 3 & 3 \\
\hline & Mean \pm SD & $3.5 \pm 0.3$ & & & & & & $3.33 \pm 1.0$ & \\
\hline \multirow{7}{*}{$\begin{array}{l}\text { Clusia alata extract } \\
(1500 \mathrm{mg} / \mathrm{kg})\end{array}$} & $\mathrm{M}_{13}$ & 3.6 & 0 & 0 & 2 & 0 & $1 \mathrm{f}, 1 \mathrm{del}$ & 4 & 4 \\
\hline & $\mathrm{M}_{14}$ & 3.1 & 1 & 0 & 2 & 0 & 1f, $1 \mathrm{r}$ & 4 & 4 \\
\hline & $\mathrm{M}_{15}$ & 4.2 & 2 & 0 & 2 & 0 & 1r, 1del & 4 & 4 \\
\hline & $M_{16}$ & 3.9 & 0 & 1 & 2 & 1 & $1 \mathrm{del}$ & 4 & 4 \\
\hline & $\mathrm{M}_{17}$ & 3.6 & 2 & 0 & 2 & 0 & 1f, 1del & 4 & 4 \\
\hline & $\mathrm{M}_{18}$ & 3.2 & 1 & 1 & 2 & 0 & 1f & 3 & 3 \\
\hline & Mean \pm SD & $3.6 \pm 0.4$ & & & & & & $3.83 \pm 0.4 *$ & \\
\hline \multirow{7}{*}{$\begin{array}{l}\text { Clusia alata extract } \\
(2000 \mathrm{mg} / \mathrm{kg})\end{array}$} & $\mathrm{M}_{19}$ & 4.6 & 1 & 1 & 2 & 0 & 1f, 2 del & 5 & 5 \\
\hline & $\mathrm{M}_{20}$ & 4.5 & 2 & 0 & 3 & 0 & 1f, 3del & 7 & 7 \\
\hline & $\mathrm{M}_{21}$ & 3.1 & 1 & 1 & 3 & 0 & 2del & 5 & 5 \\
\hline & $\mathrm{M}_{22}$ & 3.2 & 0 & 1 & 3 & 0 & 1r, 1del & 5 & 5 \\
\hline & $\mathrm{M}_{23}$ & 3.1 & 1 & 0 & 4 & 0 & 1f, $1 \mathrm{del}$ & 6 & 6 \\
\hline & $\mathrm{M}_{24}$ & 3.6 & 0 & 1 & 3 & 0 & $1 \mathrm{f}, 1 \mathrm{del}$ & 5 & 5 \\
\hline & Mean \pm SD & $3.6 \pm 0.6$ & & & & & & $5.5 \pm 0.8^{* *}$ & \\
\hline \multirow{7}{*}{$\begin{array}{l}\text { N-nitroso-N-ethylurea } \\
(50 \mathrm{mg} / \mathrm{kg})\end{array}$} & $\mathrm{M}_{25}$ & 3.2 & 3 & 1 & 12 & 0 & $1 \mathrm{f}, 3 \mathrm{r}, 6 \mathrm{del}$ & 22 & 20 \\
\hline & $\mathrm{M}_{26}$ & 5.2 & 3 & 2 & 15 & 1 & $3 \mathrm{f}, 1 \mathrm{r}, 7 \mathrm{del}$ & 27 & 27 \\
\hline & $\mathrm{M}_{27}^{20}$ & 6.1 & 2 & 1 & 12 & 1 & $2 \mathrm{f}, 3 \mathrm{r}, 8 \mathrm{del}$ & 26 & 26 \\
\hline & $\mathrm{M}_{28}$ & 6.3 & 5 & 2 & 15 & 3 & $2 \mathrm{f}, 1 \mathrm{r}, 6 \mathrm{del}$ & 27 & 27 \\
\hline & $\mathrm{M}_{29}^{20}$ & 5.6 & 5 & 2 & 11 & 1 & 2f, 7del & 21 & 21 \\
\hline & $\mathrm{M}_{30}$ & 5.2 & 3 & 1 & 14 & 1 & $2 \mathrm{f}, 2 \mathrm{r}, 8 \mathrm{del}$ & 27 & 26 \\
\hline & Mean \pm SD & $5.2 \pm 1.1 * *$ & & & & & & $25.0 \pm 2.7 * *$ & \\
\hline
\end{tabular}

*Significantly different from negative control $(\mathrm{P}<0.05)$. **Significantly different from negative control $(\mathrm{P}<$ 0.001). One hundred cells were analyzed per animal, for a total of 600 cells per treatment. $\mathrm{C}=$ chromatid-type; $\mathrm{IC}=$ isochromatid-type; $\mathrm{OA}=$ other aberrations; $\mathrm{del}=$ deletion; $\mathrm{f}=$ acentric fragment; $\mathrm{r}=$ ring; $\mathrm{SD}=$ standard deviation. 
The MI (used as a measure to evaluate cell cycle kinetics) values obtained from the analysis of 1000 cells/animal for a sample of 30 animals ( $N=6 /$ group) ranged from 3.1 to $4.6 \%$ (means) and have shown that the MI of bone marrow cells exposed to Clusia extract did not decrease, compared to those in the negative control indicating that the extract does not affect cell division.

There have been no previous studies regarding phytochemical composition specifically for the $C$. alata extract; however, these data do exist for several other Clusia species. de Oliveira et al. (1996) reported that the main components of the floral resins from five Clusia species are polyisoprenylated benzophenones, and found also as minor components, clusianone and three hitherto-unknown compounds, grandone, nemorosone, and hydroxylnemorosone. Lokvam et al. (2000) and Porto et al. (2000) analyzing phytochemically floral resins and staminal oils from about 16 Clusia species, observed that female and male floral resin chemistry does not diverge in the chemical structure of major components, such as fatty acids and polyisoprenylated benzophenones. Differences arise in the minor components and in the ratios between the major components, i.e., the chemical identity is maintained while the ratios may change between male and female resins of the same species. Some of these Clusia species present antibacterial activity (Lokvam and Braddock, 1999; Porto et al., 2000). Suffredini et al. (2006) observed that Clusia columnaris and other Clusiaceae have antibacterial and cytotoxic activity. A survey by Porto et al. (2000) on the bioactivity of all methylated and non-methylated resins and bee nest extract using bioautography (Betina, 1973) revealed that non-methylated polyisoprenylated benzophenones are largely responsible for the antimicrobial activity of pure floral resins and of the nest extract. The data obtained in the present study regarding the MI showed that the major components of the $C$. alata extract did not produce cytotoxic effects on the eukaryotic cells of the mice analyzed.

Our data obtained in this study enable us to conclude that $C$. alata crude extract has some mutagenic activity in mice bone marrow cells under the assay conditions. Since mutations are involved in the etiology of cancer due to an increased frequency of spontaneous mutation, we recommend, based on our results, that the consumption of high doses or the chronic use of Clusia alata crude extract be moderated until the development of other genotoxic and mutagenic tests can objectively determine their health risk for humans.

\section{ACKNOWLEDGMENTS}

We would like to thank the Brazilian agencies CNPq (\#306544/2006-7) and FAPESP - Fundação de Amparo à Pesquisa do Estado de São Paulo (\#2006/57514-2) for the financial support of this study, and Patrícia C. Martins for technical assistance.

\section{REFERENCES}

Armbruster WS (1984). The role of resin in angiosperm pollination: ecological and chemical considerations. Am. J. Bot. 71: $1149-1160$.

Betina V (1973). Bioautography in paper and thin-layer chromatography and its scope in the antibiotic field. J. Chromatogr. 78: 41-51.

Brendler-Schwaab S, Hartmann A, Pfuhler S and Speit G (2005). The in vivo comet assay: use and status in genotoxicity testing. Mutagenesis 20: 245-254.

Brusik DJ (1987). Principles of Genetic Toxicology. 2nd edn. Plenum Press, New York.

Cerrini S, Lamba D, Monache FD and Pinherio RM (1993). Nemorosonol, a derivative of tricyclo-[4.3.1.0 $\left.0^{3,7}\right]$-decane-7hydroxy-2,9-dione from Clusia nemorosa. Phytochemistry 32: 1023-1028. 
Cragg GM, Newman DJ and Snader KM (1997). Natural products in drug discovery and development. J. Nat. Prod. 60: 52-60. de Oliveira CMA, Porto AM, Bittrich V, Vencato I, et al. (1996). Floral resins of Clusia spp. chemical composition and biological function. Tetrahedron Lett. 37: 6427-6430.

Gustafson KR, Blunt JW, Munro MHG, Fuller RW, et al. (1992). The guttiferones, HIV-inhibitory benzophenones from Symphonia globulifera, Garcinia livingstonei, Garcinia ovalifolia and Clusia rosea. Tetrahedron 48: 10093-10102.

Hartmann A and Speit G (1997). The contribution of cytotoxicity to DNA - effects in the single cell gel test (comet assay). Toxicol. Lett. 90: 183-188.

Iinuma M, Tosa H, Tanaka T, Kanamaru S, et al. (1996). Antibacterial activity of some Garcinia benzophenone derivatives against methicillin-resistant Staphylococcus aureus. Biol. Pharm. Bull. 19: 311-314.

Klaude M, Eriksson S, Nygren J and Ahnstrom G (1996). The comet assay: mechanisms and technical considerations. Mutat. Res. 363: 89-96.

Lokvam J and Braddock JF (1999). Anti-bacterial function in the sexually dimorphic pollinator rewards of Clusia grandiflora (Clusiaceae). Oecologia 119: 534-540.

Lokvam J, Braddock JF, Reichardt PB and Clausen TP (2000). Two polyisoprenylated benzophenones from the trunk latex of Clusia grandiflora (Clusiaceae). Phytochemistry 55: 29-34.

Moore MM and Harrington-Brock K (2000). Mutagenicity of trichloroethylene and its metabolites: implications for the risk assessment of trichloroethylene. Environ. Health Perspect. 108 (Suppl 2): 215-223.

Porto AL, Machado SM, de Oliveira CM, Bittrich V, et al. (2000). Polyisoprenylated benzophenones from Clusia floral resins. Phytochemistry 55: 755-768.

Preston RJ, Dean BJ, Galloway S, Holden H, et al. (1987a). Mammalian in vivo cytogenetic assays. Analysis of chromosome aberrations in bone marrow cells. Mutat. Res. 189: 157-165.

Preston RJ, San Sebastian Jr and McFee AF (1987b). The in vitro human lymphocyte assay for assessing the clastogenicity of chemical agents. Mutat. Res. 189: 175-183.

Savage JR (1976). Classification and relationships of induced chromosomal structural changes. J. Med. Genet. 13: 103-122.

Singh NP, McCoy MT, Tice RR and Schneider EL (1988). A simple technique for quantitation of low levels of DNA damage in individual cells. Exp. Cell Res. 175: 184-191.

Sokal RR and Rohlf FJ (1995). Biometry. W.H. Freeman and Company, San Francisco, 175-205-404-486.

Speit G and Hartmann A (1999). The Comet Assay (Single-Cell Gel Test). In: Methods in Molecular Biology: DNA Repair Protocols: Eukaryotic Systems (Henderson DS, ed.). Humana Press Inc., Totowa, 203-212.

Suffredini IB, Paciencia ML, Nepomuceno DC, Younes RN, et al. (2006). Antibacterial and cytotoxic activity of Brazilian plant extracts - Clusiaceae. Mem. Inst. Oswaldo Cruz 101: 287-290.

Tice RR, Agurell E, Anderson D, Burlinson B, et al. (2000). Single cell gel/comet assay: guidelines for in vitro and in vivo genetic toxicology testing. Environ. Mol. Mutagen. 35: 206-221. 